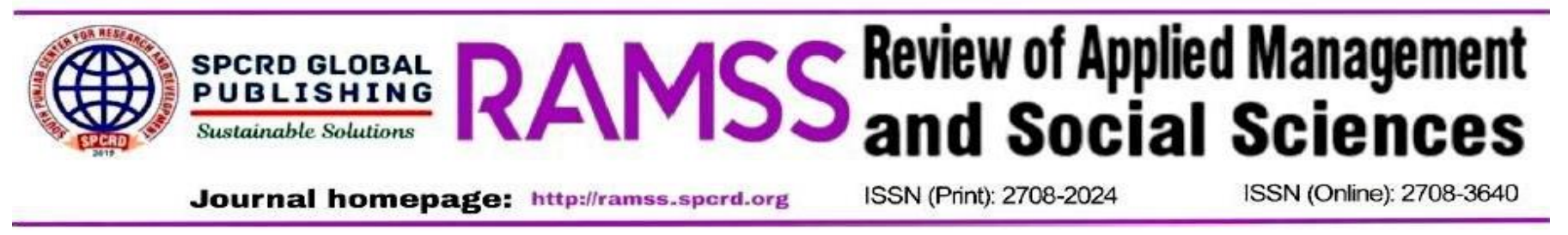

\title{
A Multimodal Analysis of Selected Placards from the 'Aurat March' 2018 of Pakistan
}

\section{${ }^{\text {a }}$ Shumaila Memon}

${ }^{a}$ Associate Professor, ELDC, Mehran University of Technology \& Engineering, Jamshoro, Pakistan Email: shumaila.memon@faculty.muet.edu.pk

\begin{tabular}{l}
\hline ARTICLE DETAILS \\
\hline History: \\
Accepted 30 April 2021 \\
Available Online June 2021 \\
\hline Keywords: \\
Multimodal Analysis, \\
Interpersonal Intersemiotic \\
Complementarity, Placards, \\
Aurat March, Ideational Features, \\
Textual Metafunction \\
\hline JEL Classification: \\
D57, D59 \\
\hline
\end{tabular}

DOI: $10.47067 /$ ramss.v4i2.147

\begin{abstract}
This study presents a multimodal analysis of selected placards from the 'Aurat March' 2018 of Pakistan. For the purpose of in-depth analysis, two placards depicting two educated women have been explored. The study is exploratory and uses Royce's framework of intersemiotic complementarity for the analysis. The findings suggest that placards are definitely more than the pieces of material resources they are constructed of. They carry in themselves various linguistic and other semiotic meanings which create a strong message in the placards.
\end{abstract}

(C) 2021 The authors. Published by SPCRD Global Publishing. This is an open-access article under the Creative Commons Attribution-

Corresponding author's email address: shumaila.memon@faculty.muet.edu.pk

\section{Introduction}

Placards have evolved as a potential and accepted norm for the manifestation of freedom of speech; they are used as striking visual/verbal props in the marches, chantings, and etc. (Bowcher, 2007). In the street demonstrations of 'Aurat March' in Pakistan, placards have evolved as a direct visual expression of disagreement with patriarchy. 'Aurat' is an Urdu word for Woman. Therefore, 'Aurat March' means 'Women's March. Since 2018, the celebration of International Women's day has taken a giant leap radically. Thousands of women, men and transgender people of different age groups, from various ethnic, social, religious and regional groups join the march in several cities in Pakistan. Since it was the first of its kind of convening street demonstration, so it used novel placards with interesting visual and verbal messages. These placards in 'Aurat March' are used as a visual form of protest against the patriarchal mindset towards women in Pakistan, conveying visual messages of confrontation. They are taken as an expressive mode of right to freedom of speech lauded and as well as loathed by some sections of society. Nevertheless, placard designers have been making them to deliver a strong message in 'Aurat March'. Their content is direct and detailed on an issue related to women in Pakistan. People, who take part in the Aurat march, hold them physically. 
In this regard, the current study aims to decipher their meaning both at verbal and visual level. This paper examines two such placards used in Aurat March 2018 by using Royce's (2007) framework. The paper explores how placards multimodally portray a complex message; which cohesively resonates with the objectives of the demonstration of Pakistani Aurat march agenda.

In 1975, United Nations announced $8^{\text {th }}$ March as International Women's Day in order to promote the goals of eradicating discrimination, granting economic, social, cultural, political, and equal legal protection to women. In 1979, United Nations General Assembly adopted an international bill of rights for women- Conventions on the Elimination of All Forms of Discrimination Against Women (CEDAW). In 1996, Pakistan endorsed CEDAW to take a national action to end inequality between women and men and ensure parity in all phases of life.

Broadly, Pakistani women's movements can be categorized into four waves (Saigol and Chaudhary 2020). Former three waves concentrated on challenging the public, social and legal sphere. However, the current fourth wave came forward as opposite to the past practices. It instead embarked on a drastic turn in the feminist panorama in Pakistan. It challenged and critiqued the sanctified private domain of the family, community, and society and thus initiated an completely fresh chapter in feminist struggles (Saigol and Chaudhary 2020).

The first wave taps back into pre-partition of India era during the nationalist struggle for the creation of Pakistan. The religious and nationalist struggles legitimized the coming out of women from homes into streets. But this emergence served somehow to the fundamental patriarchal cause and consequently didn't challenge the gendered role division. The eminent women leaders hailed from ruling families of the time and focused on the welfare and development issues which reinforced the idea of women as a nurturer for the women who are less fortunate. They worked for matters such as rehabilitation of refugees, education, health and income generation activities for poor women (Saigol and Chaudhary 2020).

Second wave of feminism witnessed the role of Sindhyani Tehreek and Women Action Forum's activism. Although, this decade of the 1980 s has been believed as a confrontational phase as it opposed the 'state's attempts to reconstitute and reorder social, economic and political structures in line with a facile ideology of Islamization articulated by a regime in search of legitimacy' (Saigol and Chaudhary 2020). These women were studied from western universities and were the founders of Women's Action Forum (WAF) (Batool et al, 2018). This wave challenged the anti- women policies which targeted women's emancipation in the social order of the country. However, it may be noted that this phase, radical in its own way, left the private sphere of women unattended. The main focus remains fixated on the public compass of politics and economics. The third wave also took on board the public sphere that draws on the legal interventions made to empower women in political dynamics.

Contrary to the former three waves, the fourth wave touched the new horizons in Pakistan and is termed as a' critical moment for feminists struggles around bodily rights and sexual autonomy' (Rehman 2019). March 2018, 'Aurat March' launched a new phase in activism that seeks to radically transform the social, economic, political and cultural milieu in which patriarchy is lived and practiced. 'Aurat March' in 2018 was originally organized under the 'Hum Aurtein' (We, the women) banner. This, later on, evolved in street demonstrations now in various cities of Pakistan. These marches are held in the autonomous capacity of feminists and separate from ties with any 
corporate, non-governmental or political party; aiming to raise voice for a socially just and equitable society. Women marching on the roads from across the Pakistan to regain their space in private and public spheres of course challenged the social and religious fabric of the country and religious scholars, politicians and good number of general Pakistani men condemned it (Azeem, 2019).

It is also pertinent to mention the potential indicators which enabled the emergence of 'Aurat March' of the fourth wave of feminism in Pakistan. One such indicator can be understood by looking at the Gender Gap Report by the World Economic Forum. In 2018, Pakistan was categorized as the second worst country in gender gap. Even women at work place seem to have been receiving the worst treatment (Azeem, 2019). This, among others were the reasons women came out to protest on the streets in the big cities initially (Batool et al, 2018). As an overall picture, 2018 Aurat March faced severe criticism particularly it was ridiculed since it was organized by the elite and upper middle women without any representation of women from other classes or other segments of the society. Nevertheless, this movement initiated raising consciousness among the common people and to alter the approaches of people (Asher, 2020). Later on, 2019, 2020 and 2021 Aurat March, attracted much bigger crowds with wide classes of women participating in it.

In all these marches, placards have been used as an important intersemiotic devices to propagate the message of the march. The current study undertakes two placards from 2018 'Aurat March' to study in details the motives of Aurat March.

\section{Literature Review}

Meaning in communication is not limited to words alone. It can be constructed through a variety of visual, aural, behavioral and other codes' too (Hodge and Kress, 1988; p. vii). Keeping in view this broader perspective, multimodal analysts have been doing work on various modes of expressions beyond the mode of language. Kress and van Leeuwen (2006, 2001) have done considerable work on images from posters, school course books, children's books, and artwork. On the other hand, O'Toole $(1995,1994)$ has studied forms of art. Other research has been looking at analyzing page-based multimodal texts. Such studies have analyzed multimodal cohesion through the framework of intersemiotic complementarity as proposed by Royce (2007a). Some have interpreted the multimodal page through SFL theory (Matthiessen, 2007). Apart from art, both page based and digital children's texts and educational texts have been studied in terms of educational registers and the role of multimodality in teaching and learning practices (e.g. Ferreira, 2007; Guo, 2004; Guijarro and Sanz, 2009; Mohan et al., 2007)

In contrast to these frameworks, some other methods have also been used such as genre analyses and corpus-based approaches for researching paper based and electronic newspapers, printed advertisements, and other types of texts (e.g. Baldry and Thibault, 2005; Bateman et.al 2007, Cheong, 2004). For placards specifically, some of the multimodal analysis of text and placards has drawn upon the Systemic Functional Linguistic (SFL) framework (Dunmire, 2009; Thompson and White, 2008). For instance, Agebedo (2012) conducted a qualitative study following Hallidays' SFL on the placards displayed over the civil protest in Nigeria over Fuel Subsidy Crisis. The data was drawn from an electronic edition of Nigerian newspapers. It was analyzed following the analytical procedure of context stratum. Bright (2018) conducted a multimodal analysis of selected placards from the bring back our girls campaign discourse on twitter. 
However, largely the scope of such studies is limited to the visual. Not many studies have explored the visual and verbal modes' intersemiotic semantic relationship. In other words, it remains yet to be done to explain that what characteristics make multimodal text visually-verbally coherent. In this vein, Royce (2007a) has introduced descriptive framework which can analyze a multimodal text both at the verbal and visual modes of communication. It vividly shows how visual and verbal modes complement to project meaning. This is said to be intersemiotic complementarity (Royce 2007a) which is used in the current study.

Royce's framework of Intersemiotic complementarity is based in the systematic Functional Linguistic view of language as 'social semiotic' (Halliday 1977) for its theoretical foundation. To understand its foundation, next section briefly discusses Halliday's views on language and the kinds of meanings it can propose.

Michael Halliday developed Systemic functional linguistics (SFL) as a model of grammar in the 1960s. It analyzes language as a social-semiotic of communicative meaning-making by taking a functional approach to grammar. Language and interaction are defined by context and this model seeks to show how contextual meaning is expressed in grammar. Halliday (1978, pp.16, 21, 27-29, \& 109) sees language in four angles: functional in terms of what it can do or what can be done with it, semantic it that it is used to make meanings, contextual in that meanings exchanged are influenced by their social and cultural situations, and semiotic in that it is a process of making meanings (Bowcher 2012).

Halliday also identifies meanings of three kinds which are expressed in human language as a whole. It forms the basis of the semantic organization of all-natural languages (Halliday, 1985). These are: Ideational metfunctions (resource for the representation of our experience of the world that is around us and inside us). Interpersonal metafunctions, which portrays the meaning as a form of action between the speaker or writer and the listener or reader. Textual metafunction, which is the resource for maintaining 'relevance to the context: both the proceeding (and following) text, and context of situation'. (Halliday, 1985, p.53).

In these three metafunctions, the reader or the spectator understands first the processes, their participants, and the circumstances, as well as relationship between one process and another; one participant and another participant if any in the same image/text. In the next step, the reader focuses on the speech functions that weather it is makes an offer, provides statements, asks questions or commands, as well as the attitudes and judgments embodied; lastly, the reader constructs the totality of the message, its relevance to the context to which it belongs, as well as the coherence in the text overall.

To cover this, Royce brings visual and the verbal modes in intersemiotic way. The next section discusses Royce's framework in more detail.

Royce's framework of intersemiotic complementarity (IC) (Royce, 1998, 1999, 2007a) builds on Kress and van Leeuwen's wrok (1996), O’Toole's studies (1994) and Halliday and Hasan's (1976) model of cohesion. This model proposes that IC relates to the semantic space that is 'synergistically' constructed when these different modes co-occur (Royce, 1999). Intersemiotic complementarity is essentially a description of multimodal coherence. 
Halliday's (1985) three metafunctions: the ideational, the interpersonal, and the textual come as the represented participants, the interactive participants, and the visual's coherent structural elements in Royce's framework. Royce's framework has modified Halliday's term textual to compositional. Because compositional creates more coherent intersemiotic message of the two modes Visual and verbal metafunctional interface.

This paper focuses on Aurat march-2018 placards. They are placard based multimodal text. Researchers have used Royce's (2007a) framework of IC for the analysis. This framework specifies a format of analyzing how visual and verbal resources interact to draw out an internally interconnected message.

\section{Methodology}

This study is qualitative. It adopted a multimodal approach. The data used for the study draws from 2 placards used in 2018 Aurat March. These were selected from the Facebook pages run by the individual organizers and Aurat March pages in 2018. Over 100 protest pictures with the protesters carrying different placards posted during March 2018 were downloaded. Out of these, a total of 02 placards which portrayed educated women were selected and subjected to a multimodal analysis. This was achieved using insights from Royce's (2007a) Intermitotic Complementarity Analysis (See table 1)

- The current study firstly labels the visual message elements, then the verbal elements of the text. Later on, it moves to see how are these intersemiotically linked. This is done by examining the categories in terms of process, participant and circumstance. This stage generates a general understanding of the worldview through the linguistic and visual structures.

- Having done the first part of cycle, the social relations between the viewer and the visual were analyzed.

- Finally, compositional features were taken account of in order to understand the structural coherence. It mainly deals with the lay out of the ideational and interpersonal elements. This phase also probes investigation in how a particular cultural and ideological the world view is constructed as a whole. 


\begin{tabular}{|c|c|c|c|}
\hline Metafunction & Visual Meanings & Intersemiotic Complementarity & Verbal Meanings \\
\hline Ideational & $\begin{array}{l}\text { Variations occur according to the } \\
\text { coding orientation. In the Natu- } \\
\text { ralistic coding we can look at: } \\
\text { Identification: who or what } \\
\text { Activity: what action } \\
\text { Circumstances: where, who with, by } \\
\text { what mean s } \\
\text { Attributes: the qualities and charac- } \\
\text { teristics } \\
\text { In the Mathematical coding we } \\
\text { can look at: } \\
\text { Identification: what } \\
\text { Relational Activity: what is the rela- } \\
\text { tion } \\
\text { Circumstances: where, what with, by } \\
\text { what mean s } \\
\text { Attributes: qualities and characteris- } \\
\text { tics }\end{array}$ & $\begin{array}{l}\text { Various lexico-semantic ways of relating the } \\
\text { experiential and logical content or subject } \\
\text { matter represented or projected in both vi- } \\
\text { sual and verbal modes through the inter- } \\
\text { semiotic sense relations of: } \\
\text { Repetition: identical experiential meaning. } \\
\text { Synonymy: the same or similar experiential } \\
\text { meaning. } \\
\text { Antonymy: opposite experiential meaning. } \\
\text { Meronymy: the relation between the part } \\
\text { and whole of something. } \\
\text { Hyponymy: the relation between a general } \\
\text { class of something and its subclasses. } \\
\text { Collocation: an expectancy or high proba- } \\
\text { bility to co-occur in a field or subject area. }\end{array}$ & $\begin{array}{l}\text { Lexical elements which relate to the } \\
\text { visual meanings. These lexical } \\
\text { items arise according to: } \\
\text { Identification (participants): who or } \\
\text { what is in volved in any activity? } \\
\text { Activity (processes): what action is } \\
\text { taking place, events, states, types } \\
\text { of behavior? } \\
\text { Circumstances: where, who with, } \\
\text { and by what means are the ac- } \\
\text { tivities being carried out? } \\
\text { Attributes: what are the qualities } \\
\text { and characteristics of the partic- } \\
\text { ipants? }\end{array}$ \\
\hline Interpersonal & $\begin{array}{l}\text { Variations occur according to the } \\
\text { Coding Orientation. In the Natu- } \\
\text { ralistic Coding-it is a continua of } \\
\text { the use of: } \\
\text { Address } \\
\text { Involvement \& Power } \\
\text { Social Distance } \\
\text { Modality Markers } \\
\text { In the Mathematical Coding-it is a } \\
\text { continua of the use of: } \\
\text { Involvement \& Power } \\
\text { Modality Markers }\end{array}$ & $\begin{array}{l}\text { Various ways of intersemiotically relating the } \\
\text { reader/ viewer and the text through MOOD } \\
\text { (Address via offers, commands, statements, } \\
\text { questions) and MODALITY (Attitude re } \\
\text { something as real or unreal, true or false, } \\
\text { possible or impossible, necessary or unnec- } \\
\text { essary, and other attitudinal positions) } \\
\text { through the intersemiotic relations of: } \\
\text { Reinforcement of address: an identical form } \\
\text { of address. } \\
\text { Attitudinal congruence: a similar kind of at- } \\
\text { titude. } \\
\text { Attitudinal dissonance: an opposite or } \\
\text { ironic attitude. }\end{array}$ & $\begin{array}{l}\text { Elements of the clause as exchange } \\
\text { which relate to visual meanings. } \\
\text { These arise according to: } \\
\text { The MOOD element in the clause real- } \\
\text { izing speech function } \\
\text { The MODALITY features of the clause } \\
\text { which express attitudes. } \\
\text { Modalization views on the possibility, } \\
\text { probability, and certainty of the } \\
\text { Proposition, as well as the use Com- } \\
\text { ment Adjuncts. Also the use of at- } \\
\text { titudinal Epithets in the form of } \\
\text { subjective adjectives. }\end{array}$ \\
\hline Compositional & $\begin{array}{l}\text { Variations in visual meanings occur } \\
\text { according to choices made in } \\
\text { terms of: } \\
\text { Information Value } \\
\text { Salience } \\
\text { Framing (weak and strong). }\end{array}$ & $\begin{array}{l}\text { Various ways of mapping the modes to realize } \\
\text { a coherent layout or composition by } \\
\text { In formation Valuation on the page } \\
\text { Salience on the page } \\
\text { Degree of framing of elements on the page } \\
\text { Inter-Visual synonymy } \\
\text { Reading Path }\end{array}$ & $\begin{array}{l}\text { The body copy as an orthographic } \\
\text { whole realized by various structur- } \\
\text { ing principles: } \\
\text { Information Value } \\
\text { Salience } \\
\text { Framing (weak and strong). }\end{array}$ \\
\hline
\end{tabular}

Table 1: Royce’s Intermitotic Complementarity Analysis Frameowrk 2007

4. Findings

\subsection{Identifying ideational features}

\subsubsection{Visual and Verbal Features}

This is the step of analysis. This requires identifying the represented participants (whether living or non-living), the processes of action (who or what is acting on what or how), the circumstances motivating the action (these could be concerned with the setting or the actors involved, or the participants who are not involved in a direct way), and the features (the qualities and characteristics of the participants) (Royce, 2007, pp. 67-70).

The main visual represented participant in placard A is a woman. Her attributes which are marks of injuries speak about the domestic violence. She seems to have been beaten and has suffered badly physical injuries. Her eyes seem to speak about the hurt she has felt. Another visual participant is her own picture: A picture within a picture. She is shown in a convocation gown indicating towards her University graduation. The background circumstances in the picture are flowers in the frame of the picture and the red color in the background hint towards love and the beauty that she might have expected in her married life. Her story about the physical injuries, want for love and care, and the past of education get unfolded into a story when we focus on the verbal

\section{ideational features.}




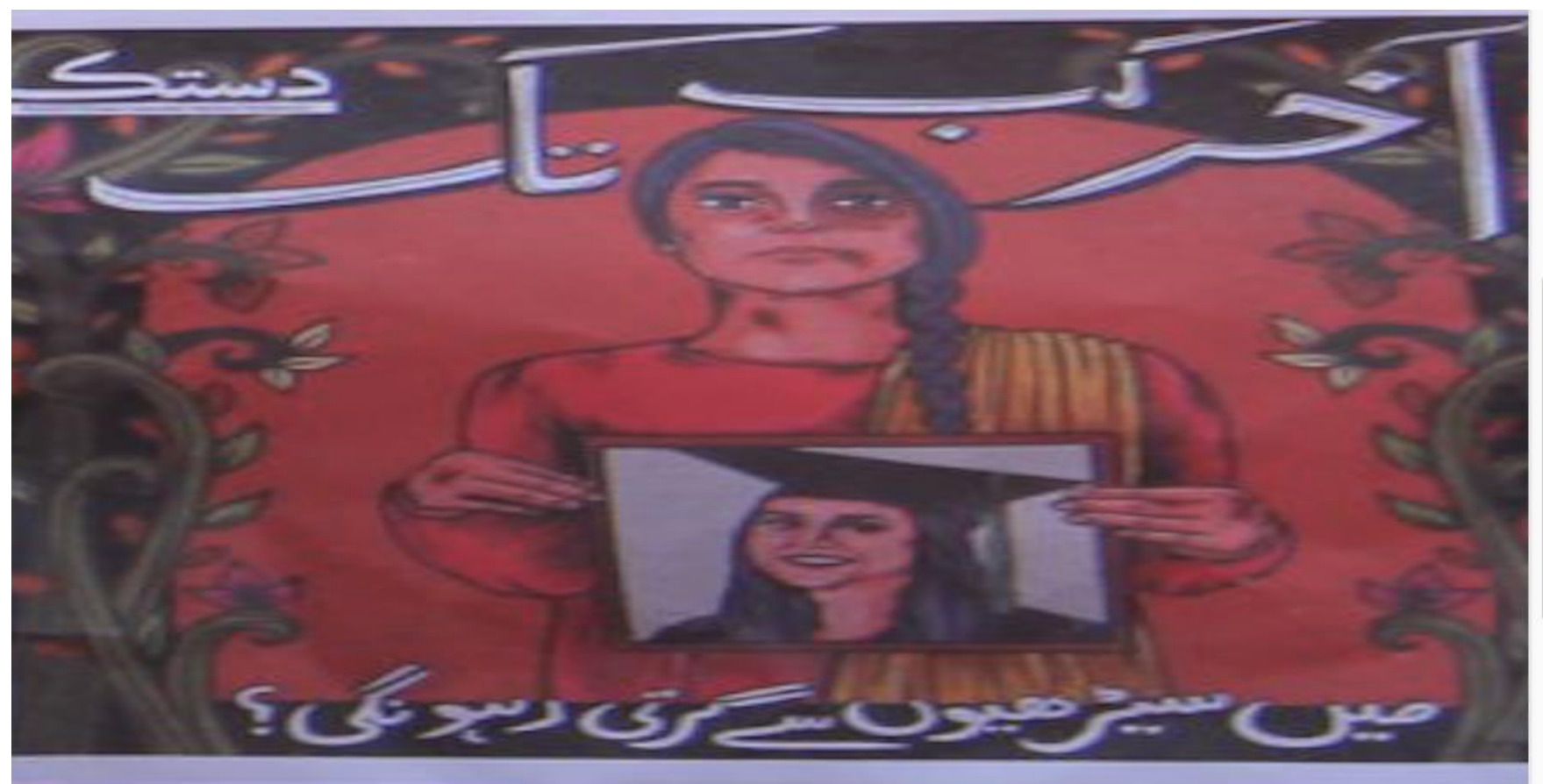

Placard A

The verbal ideational happens on two levels: first is above her head and the top of the placard. And the next is a sentence below her picture. On the top of her is written 'Akhir Kab Tak' in Urdu which can be translated as 'Untill when'. The text below the picture is 'Men Seeriyoon sey girti rahoon gi?' in Urdu and it can be translated as 'will I keep falling down the stairs?'. To accentuate this message, we need to focus on the flowery border and the color red. Red color symbolizes marriage and wedding. Flowers portray the tenderness and the delicacy. Altogether, this placard builds up a story of a married woman who is also a university graduate. A woman who had dreams of marriage being a loving and caring relationship. She seems to be a victim of domestic violence. Traditionally, many women in eastern society hide if they get beaten in order to keep the honor of family intact and also sometimes to not upset the parents. Intersemiotically, both visual and verbal parts play meronomy. Meronomy refers to the part of the whole of something. The verbal and visual messages are parts of each other and together construct the whole reality.

\section{Placard B:}

Visually, the main represented participant in placard $B$ is a woman. Her attributes- white apron and a stethoscope- sketch her as a doctor. She has neat eyebrows and outlook. There are six more participants in the image. They are present in this placard only with their hand and an arm. They play antagonist of the main character. They represent the society. The circumstances- hands on her mouth- seem to be giving suggestion/call to the main participant of shutting up, stop or suppress. These arms have verbal ideational features. Five of the hands have a question which will be discussed in the next paragraph which discusses the verbal features in this placard. The main participant-a doctor seems in social dilemma due to the questions of society on her personal and professional life and choices she makes.

The verbal features in this placard are five questions and one factual statement. They are numbered 1-3 from the right and 4-6 from the left.

1. Will you do/continue job after getting married? (Shadi ke baad nokri tau nai karogi?)

2. 85000 female doctors not working! 
3. How would you look after your children along with job? (Naukri ke sath bache kaisey sambhalogi?)

4. Will you stay out of home for overnights duties? (Poori raat bahar rahogi?)

5. You are a woman. So, why don't you specialize in gynecology? (Aap ladies hen. Gyane Q nai karleten?)

6. In future you have to cook meals/ prepare lunches-dinners? Why are you studying so much? (Itna kiya parhna. Aage ja kar rotiyan hee pakani hen?)

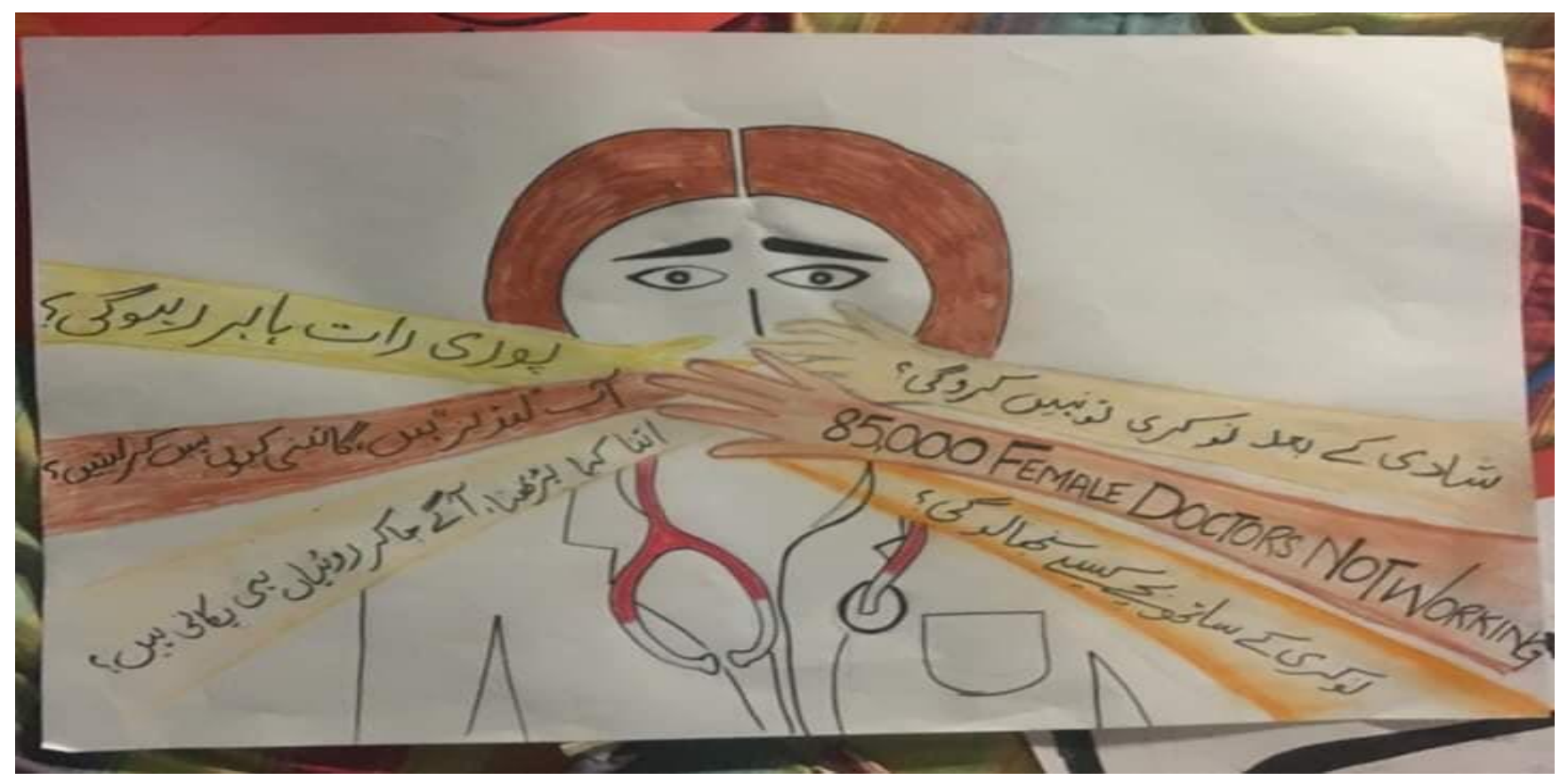

Placard B

Three of the questions $(1,3,6)$ directly question the managing marriage and profession together. They play meronomy. Altogether, these questions tend to display the conservative social mindset which takes degree as an eye catcher for good marriage proposals. They look at marriage the end goal for a woman. For a woman who has degree in medicine should not continue her professional pursuits because her primary role is that of nurturer of her immediate family. Looking after children and making food is the primary care she has to provide. Or in other words, these questions tend to create an impression that studying for a professional degree is a waste of time since future of a female doctor is also to be efficient home maker who cooks and raises children.

Next question is number 4 . It raises the concern regarding the social mobility of women and the associated questions of honor and safety for her. It poses the question that 'Will you stay out for overnight duties?' In other words, it is to make her reconsider her choice about the pursuit of career as it will involve night duties which will be problematic for her. Then comes the final question (5) (You are a woman. So, why don't you specialize in gynecology?). It implies a way out for her which technically delimits the choices for a female medical doctor. It recommends that if a woman wants to be a doctor she should pursue to be a gynecologist. The implied meaning is culturally constructed and can be that being a woman she can be with female patients. Altogether, these questions seem to force her to reconsider her choices or feel guilt. Lastly, the affirmative statement (02) $(85,000$ females doctors not working!) comes reinforcing the above story that the reason 85000 lady doctors aren't working is enough to say marriage and medical profession are antithesis to each other. Lastly, there is a statement (02) (8500o female doctors not working!) comes as a factual reminder that the 
status of female doctors that 85,000 of them do not pursue medical profession. This number comes as a further indictor for her to make decision about pursuing the career or no!

\subsection{Identifying Interpersonal Intersemiotic Complementarity}

Interpersonal meaning deals with the 'a social exchange of meanings' in a text (Halliday, 1985, p. 11). Researchers took modality, address, power relations, and social distance as the parameters of analysis in this category. Modality is understood in terms of the believability or 'truth' of the features portrayed at the visual level (Kress and van Leeuwen, 2006, pp. 154). In placard A, woman's image seems quite believable. Her tortured body and pain in eyes speak about the turmoil in her soul. Placard B, portrays a lady doctor with 6 hands stifling her mouth. These hands are metaphorically depicting the attitudes of society. Since these notions are prevalent very commonly in Pakistani society so this placard is believable.

From the perspective of social distance, involvement and address, Placard A is a picture within a picture; frame within a frame. One woman intricately presents two identities of hers which are in conflict with each other. This placard involves audience directly into the action by putting up an address of a question to them about her respite?

On the contrary, placard B is a closeup of the woman. She isn't directly putting up a question to the spectator but rather seems stifled and confused due to the questions raised to her. The eyes of women are directly looking into the eyes of spectator so that the level of engagement with the viewer is high. There is no further action happening in the background. In both the placards, the mouth of the main character is forcefully shut. The helplessness in the eyes of the main characters makes the viewer think and partake in the action that what could be the solution. From the power relation perspective, the placard designer has brought the women in Placard A as divided in two contrasting identities of hers and text is main. Verbal and Visual features are crossing each other in opposite directions. Both working women are unable to do good for themselves in spite of being educated. Action in both is changed into tense due to the verbal tension.

\subsection{Compositional Intersemiotic complementarity}

Different kinds of meanings can be constructed through a various discourse frameworks which enable creating our understanding of social reality they denote (Ramakrishnan 2012). Compositional intersemiotic complementarity deals with the way the various semiotic modes compositionally correspond on the page with each other to present a coherent layout or composition (Kress and van Leeuwen, 2006, pp. 175).

Contextually, these placards portray the attitudes of demonstrators towards what a woman suffers. Since these demonstrations majorly take place in big cities, so they also depict the problems an educated woman undergoes. Compositionally, Placard, has three divisions: upper part, middle part and the bottom. The middle part takes up the most space but verbally, the upper part comes out as dominant since it has the largest font. The questions come as loud and guides the spectator to see the picture critically. While Placard B, compositionally is taking all action in the middle part. The lady doctor and the society's emerging questions are all centrally laid to emphasize the helplessness and involve the spectator.

\section{Conclusion}

This study aimed to explore the meanings built through the placards used in the 'Aurat 
March' 2018. Overall, these selected placards portray the issue of women who in spite of education suffer the domestic violence and social pressure. Some of the prominent themes 'Aurat March' is organized are women empowerment, gender equity in society gender-based violence at home, in public spaces, at workplaces, and violence against women's bodies. The placards taken in the analysis in the current study also portray visually and verbally these issues. As Bowcher (2012) believes that placards have transformed into a promising and accepted norm for the expression of freedom of speech so does this paper concludes that in Pakistani 'Aurat March' too they use striking visual/verbal messages. This study is limited to the analysis of two placards which represent the educated section of women. However, future research studies may take more placards and also explore analysis on placards which represent women of myriad backgrounds and has multiple other issues.

\section{References}

Agbedo, C.U., (2012) Placards as a Language of Civil Protest in Nigeria: A Systematic Functional analysis of the Fuel Subsidy Crisis, IOSR Journal of Humanities and Social Science (JHSS) 6 (2) p.17-26

Asher, S. (2020, March 7) Pakistan on Knife Edge over Women's March. BBC News. https://www.bbc.com/news/world-asia-51748152

Azeem, T (2019) Pakistan's women Marched for Their Rights, Then the Backlash Came. The Diplomat. Accessed at https://thediplomat.com/2019/03/pakistans-women-marched-for-their-rightsthen-the-backlash-came on March 8, 2020

Baldry, A. and Thibault, P. (2005) Multimodal Transcription and Text Analysis: A Multimedia Toolkit and Coursebook with Associated On-line Course (London: Equinox).

Barthes, R. (1977) Image-Music-Text (London: Fontana). Bateman, J. (2008) Multimodality and Genre: A Foundation for the Systematic Analysis of Multimodal Documents (Basingstoke and New York: Palgrave Macmillan).

Bateman, J., Delin, J. and Henschel, R. (2007) 'Mapping the Multimodal Genres of Traditional and Electronic Newspapers'. In T. D. Royce and W. L. Bowcher (eds.) New Directions in the Analysis of Multimodal Discourse (Mahwah, NJ: Lawrence Erlbaum Associates), pp. 147-72.

Batool, S., Batool, F., Zia, A., \& Saeed, R. (2018). The Struggle for Women Rights: A Study of Emergence of Feminism in Pakistan, (1947-2010). Journal of the Punjab University Historical Society. 31 (1)

Bright, F. O., (2018) A Multimodal Analysis of Selected Placards From the \#Bring Back our Girls Campaign Discourse on Twitter, International Journal of Latest Research in Humanities and Social Science 1 (11) p.67-76

Bowcher, W.L. (2012) 'Multimodality in Japanese Anti-War Placards. In Multimodal Texts from Around the World: Cultural and Linguistic Insights (Palgrave Macmillan), p. 217-245.

Bowcher, W. L. (2006) 'Networking the Field of Page-based Instructional Multimodal Texts'. In M. Amano (ed.) Multimodality: Towards the Most Efficient Communications by Humans, Proceedings of the Sixth International Conference: Studies for the Integrated Text Science (Nagoya: Graduate School of Letters, Nagoya University), p. 1-16.

Bowcher, W. L. (2007a) 'A Multimodal Analysis of Good Guys and Bad Guys in "Rugby League Week”'. In T. D. Royce and W. L. Bowcher (eds.) New Directions in the Analysis of Multimodal Discourse (Mahwah, NJ: Lawrence Erlbaum Associates), pp. 239-74.

Bowcher, W. L. (2007b) 'Field and Multimodal Texts'. In R. Hasan, C. Matthiessen and J. Webster (eds.) Continuing Discourse on Language: A Functional Perspective, Vol. 2 (London: Equinox), pp. 619-46. 
Bowcher, W. L., Kishida, A., Nakamura, T. and Ota E. (2005) 'Constructing the "other” in Japanese posters for peace rallies'. Conference presentation at the International Systemic Functional Congress, ISFC 2005, 17-22 July, Sydney, Australia.

Cheong, Y. Y. (2004) 'The construal of ideational meaning in print advertisements'. In K. O’Halloran (ed.) Multimodal Discourse Analysis: Systemic Functional Perspectives (London: Continuum), pp. 163-95.

Dunmire, P. L. (2009) “"9/11 Changed everything”: An Intertextual Analysis of the Bush Doctrine'. Discourse \& Society 20(2): 195-222

Ferreira, A. (2007) 'Japanese Semiotic Vernaculars in ESP Multiliteracies Projects' In T. D. Royce and W. L. Bowcher (eds.) New Directions in the Analysis of Multimodal Discourse (Mahwah, NJ: Lawrence Erlbaum and Associates), p. 299-329.

Guo, L. (2004) 'Multimodality in a Biology Textbook'. In K. O’Halloran (ed.) Multimodal Discourse Analysis: Systemic Functional Perspectives (London: Continuum), pp. 196-219.

Guijarro, A. J. M. and Sanz, M. J. P. (2009) 'On Interaction of Image and Verbal Text in a Picture Book: A Multimodal and Systemic Functional Study’. In E. Ventola and A. J. M. Guijarro (eds.) The World Told and the World Shown: Multisemiotic Issues (Basingstoke and New York: Palgrave Macmillan), pp. 107-23.

Halliday, M. A. K. (1977) 'Text as Semantic Choice in Social Contexts'. In T. A. Van Dijk and J. S. Petofi (eds.) Grammars and Descriptions: Studies in Text Theory and Text Analysis (Berlin: Walter de Gruyter), pp. 176-225.

Halliday, M. A. K. (1978). Language as Social Semiotic. London: Edward Arnold.

Halliday, M. A. K. (1985). An Introduction to Functional Grammar. London: Edward Arnold.

Halliday, M. A. K., \& Hasan, R. (1976). Cohesion in English. London: Longman.

Hodge, R. and Kress, G. (1988) Social Semiotics (Cambridge: Polity Press).

Kress, G., \& van Leeuwen, T. (1996). Reading Images: The Grammar of Visual Design. London: Routledge.

Kress, G. and van Leeuwen, L. (1996) Reading Images: The Grammar of Visual Design (London: Routledge).

Kress, G. and van Leeuwen, T. (2001) Multimodal Discourse: The Modes and Media of Contemporary Communication (London: Arnold).

Kress, G. and van Leeuwen, T. (2006) Reading Images: The Grammar of Visual Design (2nd edn) (London: Routledge).

Matthiessen, C. (2007) 'The Multimodal Page: A Systemic Functional Exploration'. In T. D. Royce and W. L. Bowcher (eds.) New Directions in the Analysis of Multimodal Discourse (Mahwah, NJ: Lawrence Erlbaum and Associates), pp. 1-62.

Mohan, B., Slater, T., Kobayashi, E., Luo, L. and Kobayashi, M. (2007) 'Multimodal Scientific Representations across Languages and Cultures'. In T. D. Royce and W. L. Bowcher (eds.) New Directions in the Analysis of Multimodal Discourse (Mahwah, NJ: Lawrence Erlbaum and Associates), pp. 275-98.

O'Halloran, K. (1999) 'Towards a Systemic Functional Analysis of Multisemiotic Mathematics Texts'. Semiotica 124-1(2): 1-29.

O’Toole, M. (1994). The Language of Displayed Art. London: Leicester University Press.

O'Toole, M. (1995). A Systemic-functional Semiotics of Art. In P. Fries \&M. Gregory (Eds.), Discourse in Society: Systemic Functional Perspectives (Vol. L, pp. 159-179). Norwood, NJ: Ablex.

Ramakrishnan (2012) 'In India, Nobody Wants to be Dark: Interpreting the Fairness Ideology through Intersemiotic Complementarity' In W.L Bowcher (ed), Multimodal Texts from Around the World. (Palgrave Macmillan) p. 175-195 
Rehman, Z (2019) 'Aurat March and Undisciplined Bodies: Articulating a History of Sexuality in Pakistan', accessed at https://medium.com/@zoya_rehman/aurat-march-and-undisciplined-bodiesf6f23ada0318 on March 9, 2021

Royce, T. (1998a). Visual-verbal Intersemiotic Complementarity in The Economist Magazine. Unpublished Doctoral Dissertation, University of Reading, United Kingdom.

Royce, T. (1998b). Synergy on the page: Exploring Intersemiotic Complementarity in Page based Multimodal Text. In JASFL Occasional Papers.

Royce, T. D. (2007a) 'Intersemiotic Complementarity: A Framework for Multimodal Discourse Analysis'. In T. D. Royce and W. L. Bowcher (eds.) New Directions in the Analysis of Multimodal Discourse (Mahwah, NJ: Lawrence Erlbaum Associates), pp. 63-110.

Royce, T. D. (2007b) 'Multimodal communicative competence in second language contexts. In T. D. Royce and W. L. Bowcher (eds.) New Directions in the Analysis of Multimodal Discourse (Mahwah, NJ: Lawrence Erlbaum Associates), pp. 361-90.

Saigol, R., and Chaudhry. N. U., (2020) Contradictions and Ambiguities of Feminism in Pakistan: Exploring the Fourth Wave. (Friedrich-Ebert-Stiftung, Pakistan Office).

Thompson, E. A. and White, P. (2008) Communicating Conflict: Multilingual Case Studies of the News Media (London: Continuum).

Unsworth, L. (2001) Teaching Multiliteracies Across the Curriculum: Changing Contexts of Text and Image in Classroom Practice (Buckingham: Open University Press).

Unsworth, L. (2004) 'Comparing school sciences Explanations in Books and Computer- based Formats: The Role of Images, Image/text relations and hyperlinks'. International Journal of Instructional Media 31(3): 283-301.

Unsworth, L. (2007) 'Multiliteracies and Multimodal Text Analysis in Classroom Work with Children's Literature'. In T. D. Royce and W. L. Bowcher (eds.) New Directions in the Analysis of Multimodal Discourse (Mahwah, NJ: Lawrence Erlbaum and Associates), p. 331-59. 